\title{
シドニー都市圈の都市周辺農村における 農業的土地利用変化とその持続的性格
}

\author{
一ペンリス市キャスルレイ地区の事例一
}

菊 地 俊 夫*

\section{Agricultural Land Use Changes and their Sustainability in the Urban Shadow of the Sydney Metropolitan Region, Australia: \\ A Case Study of Castlereagh Area, Penrith City}

\author{
Toshio KIKUCHI *
}

\begin{abstract}
In this paper the author analyses agricultural land use changes in the urban shadow of the Sydney metropolitan region and clarifies their sustainability on a micro-scale using the example of Castlereagh area, Penrith City. Castlereagh area is situated around the western suburbs of Sydney city centre, and is characterised by competition between agricultural and urban land use. In this area, rural and agricultural land use has generally developed since the colonial period. Although definite changes from agricultural to urban land use are not apparent with the advancement of urbanization, some kinds of agricultural use have changed to others in terms of function and quality since the 1990s. This sustainability of agricultural land use changes based on land, climate, and historical conditions as a suitable region for agriculture, and accessibility to the urban market for agricultural products, and land use policy of city planning and land use zoning.

In Castlereagh area dairy farming and sheep grazing have traditionally developed with advantageous land and climate conditions for grass production. In particular, suburban dairy farming was important for town milk production. Although there were a few trends of conversion from dairy farming to sheep grazing, because of a decreasing agricultural labour force, the framework of traditional pastoral farming still remained until the $1980 \mathrm{~s}$. Since the 1990s most aspects of pastoral farming have changed into horse raising, horticulture, and hobby farming with the enlargement of urban land use for residential and factory sites. Such farming has been most apparent among all kinds of land use in the 1990s.

Under an environment of urban shadow, both horse raising and horticulture have developed due to their suitability for expanding urban land use and farmland subdivisions. Agricultural land use changes are supported by economic factors such as capital intensity and high profitability. On the other hand, hobby farming is less intensive and rather unprofitable,

* 東京都立大学大学院理学研究科地理学教室

* Department of Geography, Tokyo Metropolitan University
\end{abstract}


and is developed for the mental satisfaction of aged and the urban residents, rather than the advancement of urbanisation and land subdivision. Therefore, agricultural land use changes into hobby farming are supported by non-economic factors such as productive aging and mental satisfaction. On the whole, a series of agricultural land use changes are identified for their sustainability, and are supported by economic and non-economic factors. In particular, hobby farming plays an important role in holding back urban sprawl and maintaining agricultural land use.

Key words: Sydney metropolitan region, urban shadow, agricultural land use, sustainability, hobby farm, land subdivision

キーワード：シドニー都市圈，都市周辺農村，農業的土地利用，持続性，ホビーファーム，土地の細 分化

\section{I. 序 論}

都市地域における土地利用の特徵は，さまざま な形態やパターンが無秩序に混在し, 農業的土地 利用が都市的機能の土地需要の増大にともなって, 都市的土地利用に不規則に変化することである (Pryor, 1968； Ilbery，1985）。特に，市街地周 辺の近郊農村地域（urban fringe）は急速な都市 化による土地利用変化で特徵づけられている。そ こでは, 農業的土地利用が住宅地の拡大や工場用 地の開発などにより都市的土地利用に変化し，単 位土地面積当たりの地代や収益性の拡大がみられ るとともに，土地売買の投機的な活動が集中して いる（Bryant, 1973，1981，1984;Best, 1981; Bryant and Coppack, 1991)。しかし, 都市近郊 の農村地域における都市化の進展は, 土地利用規 制や土地税制などの政策・制度，あるいは農業的 土地利用や農業経営の形態により地域的に異なっ た様相を呈している（Blair, 1980;Bowler, 1984）。 例えば, ニュージーランドのオークランド近郊で は, 資本集約型の軽種馬飼養や果樹園芸農業が収 益性の高い土地利用として発達し, 都市化の進展 にともなう土地利用変化に対して強い抵抗を示し ていた（Moran, 1978, 1979, 1980 ; 菊地・モ ラン, 1990 ; 菊地, 1994$)$ 。

他方, 都市周辺農村 (urban shadow) や後背 農村（rural hinterland）の土地利用では, 都市
的要素の影響の現われ方は市街地との距離や関係 位置, あるいは農業的土地利用や農業経営の立地 環境・形態により異なっているが, 農業景観や農 村的性格が依然として強く残されている。しかし， 都市周辺農村では都市的要素の影響が少なからず 現われ, 農業労働力の減少や労働粗放的な農業生 産が景観的に目立つようになる。特に, 都市中心 部への交通に恵まれた都市周辺農村では, 兼業農 家や在宅通勤者が増加し, 農業的土地利用と都市 的土地利用の競合は分散的な住宅地開発によって 顕在化している。このような土地利用の競合にお いても, 農業的土地利用の形態や農業収益性の地 域的な差異, あるいは機械・施設などの単位土地 面積当たりの資本投入量や農業経営者の意思決定 の地域的差異が競合の程度や土地利用変化の速度 を決定づける大きな要因となっている（Bryant and Johnston, 1992)。

以上のように，都市地域の土地利用に関する従 来の研究の多くは, 個々の土地利用の空間的配置 とその変化要因の分析に主眼を置いてきた。土地 利用の空間的配置に関しては,さまざまなタイプ の農業的土地利用が都市を中心としてチューネン モデルやシンクレアモデルのような配置をするか どうかが検討されてきた（Russwurm，1980； Bryant et al., 1982 ; Mather, 1986 ; Bryant and Johnston，1992）。また, 土地利用変化に関 する要因分析では, 都市的土地利用の需要拡大や 
都市的産業の雇用増大, あるいは都市の農産物市 場の増大など都市を中心にその直接的な影響が強 調されてきた（Sinclair, 1967 ; Griffin, 1973； Munton, 1974;Blair, 1980;Rhind and Hudson, 1980 ; Bowler, 1984 ; Mather, 1986)。しかし, このような都市化の影響が土地利用変化の要因の 一部にすぎないことや, 土地利用変化がさまざま な環境要因のなかで動態的システムとして捉えら れなければならないことは, その後の地理学の研 究で指摘されている (Munton, 1974; Bryant et al., 1982;Pacione, 1986;Bryant and Johnston, 1992）。つまり, 都市化の要因とともに, 都市地 域を取り巻く自然環境 (土地条件や気候条件), 社 会・経済環境（技術革新やインフラストラク チャー, 土地所有, 農業の近代化と合理化, 政策・ 制度), 歴史·文化環境 (生活水準や生活文化, 文 化集団, 開発の歴史) が土地利用変化の要因とし て取り上げられ，それらの要因の相互関連から土 地利用変化が検討されてきた（菊地・モラン, 1990 ; 菊地, 1994 ; 菊地 $\cdot$ 堤, 1998 ; 菊地・鷹 取, 1999)。

特に菊地・モラン（1990）と菊地（1994）は, 土地利用変化に関するさまざまな環境要因が有機 的に関連し, 土地利用変化がフィードバックする システムとフィードバックしないシステムがつく られることを明らかにした。これらのシステムは 土地利用の変化のしにくさと, 変化のしやすさに 影響を及ぼしていた。しかし，土地利用変化が フィードバックするシステムが土地利用変化の持 続的性格とどのように関連するのかの検討は不十 分であった。土地利用変化の持続的性格とは, 土 地利用変化は多少なりともあるが，農業的土地利 用と都市的土地利用の枠組みや構成が大きく変化 することなく維持されることである。つまり, 農 業的土地利用に関していえば，ある種の農業的土 地利用が他の農業的土地利用に変化することで, 都市的土地利用への変化が抑制され, 結果的には 農業的土地利用と都市的土地利用の枠組みや構成 を大きく変化させることなく, 農業的土地利用が 維持されている。このことを，農業的土地利用変 化の持続的性格と考えた（田林・菊地，2000）。
しかし，土地利用変化の持続的性格に関する地域 的条件や存立基盤は十分に検討されているとはい えず，それらを体系的に分析することが地理学と その関連科学の課題の 1 つになっている。

そこで, 本研究はシドニー都市圈において農業 的土地利用と都市的土地利用の競合が現れはじめ ている都市周辺農村に注目し，そこでの農業的土 地利用の時間的・空間的変化を分析した。さらに, 本研究は地域的性格を形成する諸要因の有機的な つながりを踏まえて, 農業的土地利用変化の持続 的性格とその存立基盤を明らかにした。研究の対 象となるシドニー都市圈はニューカッスル都市圈 (1996 年現在で人口約 47 万) とウロンゴング都市 圈（1996 年現在で人口約 25 万）を含むシドニー 大都市圈 (Sydney Great Metropolitan Region) の一部であり（Department of Planning, 1995), 人口規模は 1996 年現在で約 380 万とオーストラ リア最大の都市圈である。シドニー都市圈では, 都市的土地利用の拡大が都市機能や人口の集中に よって第 2 次世界大戦以降に加速されたが, 農業 的土地利用は先進国の大都市圈に比べて比較的広 く維持されている（Heathcote, 1994 ; Environment Protection Authority，1995)。そのため, シドニー都市圈は農業的土地利用変化とその持続 的性格を分析する格好の事例地域となっている。 特に, シドニー都市圈では農業的土地利用変化の 持続的性格が農業的土地利用から都市的土地利用 への変化のしにくさとして顕在化しており，その 存立基盤は地域を取り巻く環境諸条件の有機的な つながりを的確に反映している。

シドニー都市圈は市郡を単位に 43 の地区に区 分され, それらの地区ごとに国勢調查や農業セン サスの統計データが得られる ${ }^{1)}$ 。本研究は地区ごと の統計デー夕に基づいて, 農業的土地利用の地域 的差異を明らかにするとともに，農業的土地利用 変化の持続的性格を示す典型的な地区を抽出した。 さらに, 事例地区の空中写真や現地調査から過去 と現在の土地利用図を作成し，それらを比較し， 農場の聞き取り調査のデー夕を補いながら, 農業 的土地利用変化の分析を行った。特に, 農業的土 地利用変化の持続的性格に着目し, その基盤が自 


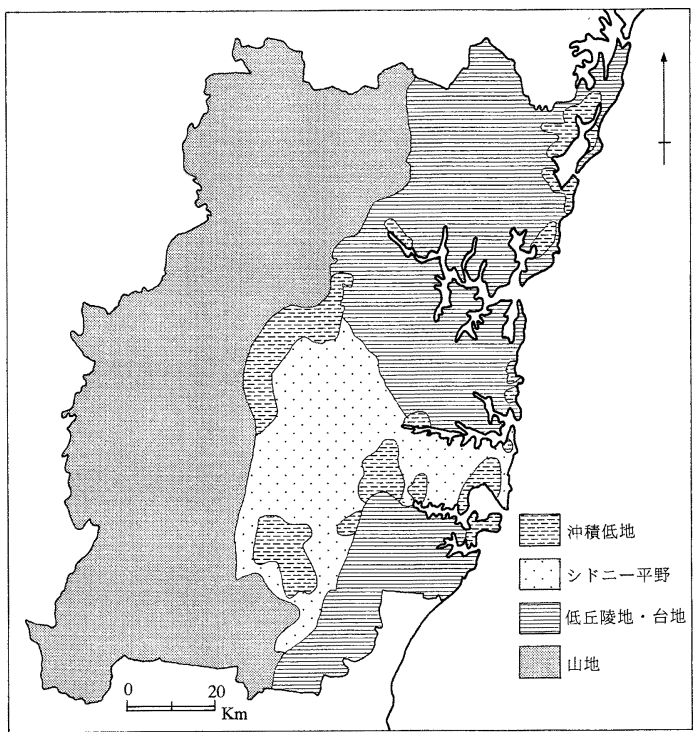

図 1 シドニー都市圈の地形条件.

(Environment Protection Authority（1995）により 作成)

Fig. 1 Topographical conditions in the Sydney metropolitan region.

然的環境，社会・経済的環境，歴史·文化的環境 の相互関係によって，どのように構築されている のかを考察した。

\section{II. シドニー都市圏における市街地の 拡大と土地利用計画}

現在のシドニー都市圈は，タスマン海とグレー トデイバイディング山脈に挟まれた幅 $100 \mathrm{~km}$ 程 度の帯状の地域に立地し, その地域は一部に沖積 低地を含むシドニー平野と低丘陵地（北部のホー ンスビイ台地と南部のウォロノラ台地)，および山 地などの地形からなっている（図 1)。シドニー地 域の気候は温暖湿潤であり，最暖月（1月）と最 寒月（7月）の平均気温がそれぞれ $22.6^{\circ} \mathrm{C}$ と 12.2 ${ }^{\circ} \mathrm{C}$ で, 年降水量は $1,176 \mathrm{~mm}$ である。したがって, シドニー地域の地形や気候などの自然環境は西 ヨーロッパのものと類似して抢り，入植したヨー ロッパ人に良好な居住環境を提供していた。

シドニー都市圈における市街地の外延的拡大を 検討するため, 1995 年の地区別人口分布と, 1968

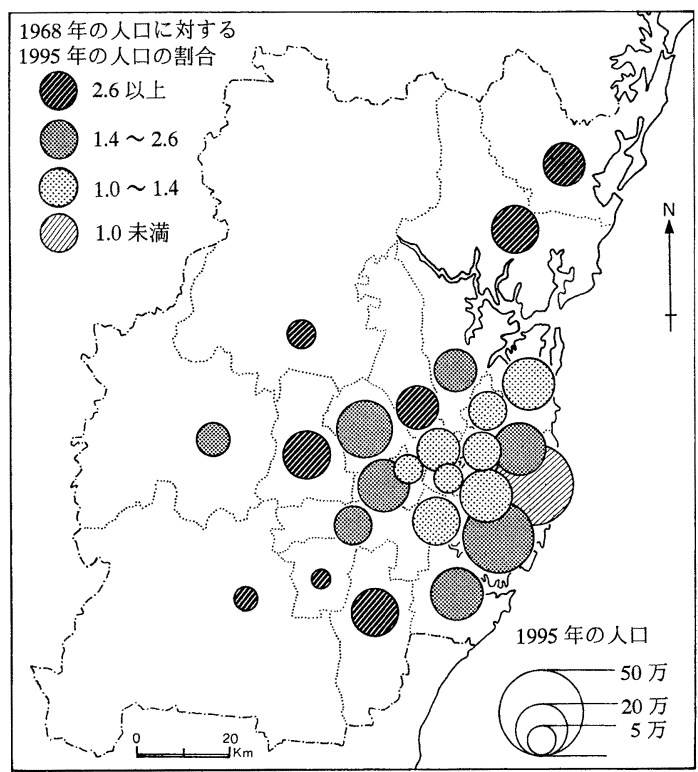

図 2 シドニー都市圈における人口分布（1995 年） とその増加率（1968-1995 年).

(Local Statistics of New South Wales と Regional Statistics of New South Wales に より作成)

Fig. 2 Distribution of population and its increasing rate in the Sydney metropolitan region.

年の人口に対する 1995 年の人口の増減傾向を図 2 に示した。これによれば，シドニー都市圈の中心 部では 1968 年の人口に対する 1995 年の人口が 1.0 未满と, 人口分布の空洞化が進んでいることが わかる。これは, 都市機能やオフィス機能が中心 部において集積するようになり, 都市の居住機能 が郊外に立地移動したためである。都市圈の中心 部とは反対に，その周辺では人口が 1968 年から 1995 年にかけて約 1.4 倍以上に増加しており, 市 街地の拡大が進んでいることがわかる。

シドニー都市圈における市街地の拡大には，3 つの方向性があることも図 2 から識別できる。第 1 はシドニーの都市中心部から西に向かう国道 32 号 (Great Western Highway) と郊外高速鉄道の 交通基軸に沿った市街地の拡大である。これは, ヨーロッパ人の入植時代から現在まで人々が基本 的に指向してきた海岸部から内陸部へ向かう拡大 
の方向性であった。第 2 は都市中心地から南西に 向かう拡大である。これは, シドニーーキャンベラ ーメルボルンの主要都市を結ぶ交通幹線に沿った もので, 拡大の方向性はキャンベルタウンなどい くつかのニュータウンの建設などによって確かな ものになった ${ }^{2)}$ 。第 3 は南北の方向性をもって拡 大するものであり, ウロンゴングとシドニー，お よびニューカッスルの 3 つ都市圈を結びつけて いる。この都市拡大の方向性は, それぞれの工業 都市を結びつけるものであり, 20 世紀以降の工業 発展に支えられたコナーベーションでもあった。

都市発展の 3 つの方向性は交通ネットワークと 主要都市との結びつきを基盤につくられているが, 土地条件や社会・経済条件, あるいは政策や計画 も重要な基盤になっている。特に, 土地条件は市 街地の拡大にとって重要であり, 都市的土地利用 に転換しやすい平坦地がシドニー都市圈の西部と 南西部に広がっていることは西や南西方向の市街 地の拡大の基礎的な条件になった（図 1)。しかし， 平坦地は農業適地であることが多いため, 農業的 土地利用と都市的土地利用との競合が著しく, 結 果として土地収益性の高い都市的土地利用が無秩 序に拡大する傾向にあった。そのため, ニューサ ウスウェールズ州政府はシドニー都市圈における 土地利用の適正配置を図って, Sydney Region Outline Plan 1967 年に策定した。この計画は 1988 年の Metropolitan Strategyによって見直 されたが, 都市圈における土地利用の配置や市街 地の拡大の方向性を, 土地利用ゾーニング（土地 利用規制）によってある程度コントロールしよう とする枠組みは変わらなかった（Department of Planning, 1995)。

Metropolitan Strategyにおけるシドニー都市 圈の都市計画図によれば（図 3), 基本的な土地利 用ゾーニングは都市域, 農村域, グリーンベルト, 森林域の 4 つである。都市域は都心を中心とする 市街地であり, 都心から約 $30 \mathrm{~km}$ の圈域と幹線道 路に沿った帯状の地域が主に含まれている。都市 域のほとんどの空間は都市的土地利用で占められ ている。農村域は沖積低地のように土地条件の良 好な農業適地を広く含み, 伝統的には小麦生産や

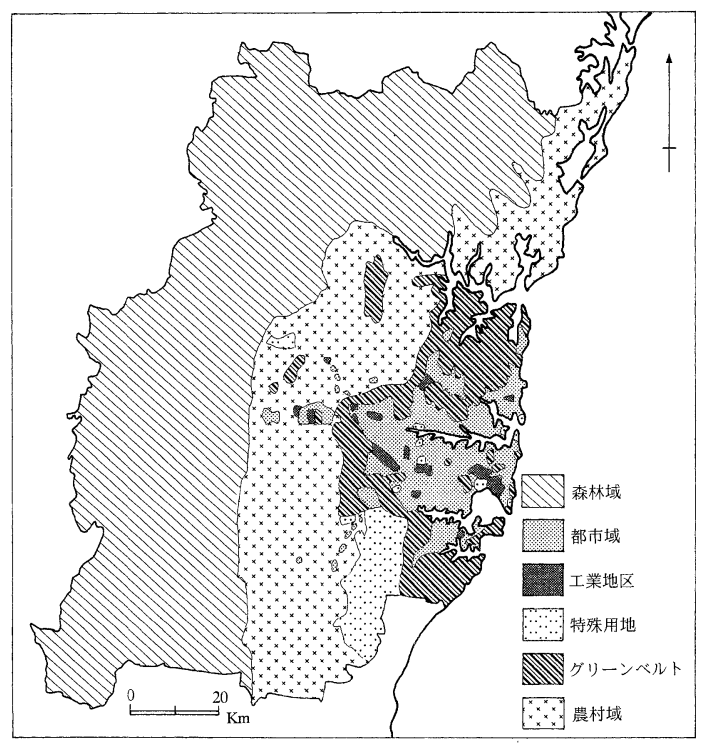

図 3 シドニー都市圈における土地利用ゾーニング. (Department of Planning（1995）により作 成)

Fig. 3 Land use zoning in the Sydney metropolitan region.

酪農業，あるいは牧羊業が土地利用の中心になっ ている。しかし, 農業的土地利用と都市的土地利 用の競合が著しく, 都市的土地利用の拡大がグ リーンベルトの設定などさまざまな方策で抑制さ れている。グリーンベルトは市街地化した都市域 を取り囲むようにゾーニングされ, 緑地公園の建 設や保全林・公有林の設定だけでなく, 荒地や雑 木林などのアーバンブッシュを残すことやオープ ンスペースを設定することによって ${ }^{3)}$, 緑地の保全 と都市的土地利用拡大の抑制が図られている (Department of Planning, 1991)。他方, 森林 域はシドニー都市圈の西部に広がるブルーマウン テン国立公園や州立公園, 州有林, および軍用地 などを含み，その分布は山地や低丘陵地に広がっ ている。

シドニー都市圈の土地利用ゾーニングでは, グ リーンベルトや森林域への都市的土地利用の侵入 は計画的に抑制されていたのに対して，農村域へ の都市的土地利用の侵入は, UDP (Urban 
Development Programme）などの都市計画の検 討を受けて容認されることもあった。実際，農村 域の林地や荒地には都市計画に基づく工業団地や 住宅団地が点在して建設され，それらがアーバン スプロールの原因となり, 既存の市街地と連担し たりすることもあった。また，都市的土地利用が グリーンベルトを越えて郊外に拡大することも少 なくなかったが，シドニー都市圈全体では土地利 用ゾーニングの枠組みは広い土地とその空間的な 余裕，および低密度な人口分布によってほぼ維持 されてきた。しかし第 2 次世界大戦以降, 国道 32 号沿いの地区では都市的土地利用の拡大が著しく, 土地利用ゾーニングもしばしば修正されてきた。 さらに, 2000 年のシドニーオリンピックのメイン 会場がパラマッタ周辺に建設されたことも, 国道 32 号沿いの都市化を促進させる要因の 1 つになっ ている。そのため, シドニー都市圈の都市計画の なかでは, 農業的土地利用と都市的土地利用の競 合が著しく, 農業的土地利用変化が多くみられる のは, 国道 32 号沿いの地区と一般に考えられてい

る (Department of Planning, 1995)。

\section{III. シドニー都市圏における農業的 土地利用変化の地域的差異}

\section{1）農業的土地利用の推移と分布}

シドニー都市圈における農業的土地利用の推移 を人口の増減と関連して検討するため図 4 を作成 した。これによれば，シドニー都市圈の農業的土 地利用の推移は大きく 3 つの時期に区分できる。 すなわち,これらは 1976 年までの農業的土地利用 の高位安定期と 1977 年から 1987 年までの農業的 土地利用の急減期, および 1988 年以降の農業的 土地利用の低位安定期の 3 つである。

農業的土地利用の高位安定期においては, 耕作 地と樹園地, および牧草地や放牧地を含めた農業 的土地利用は漸減する傾向にあったが, 雑木林や 荒地などのアーバンブッシュの農地化や耕作放棄 地の再農地化によって一時的に増加することも あった。全体的には, シドニー都市圈の人口が ヨーロッパからの移民によって急増しているにも かかわらず，20万 ha 以上の広がりをもつ農業的

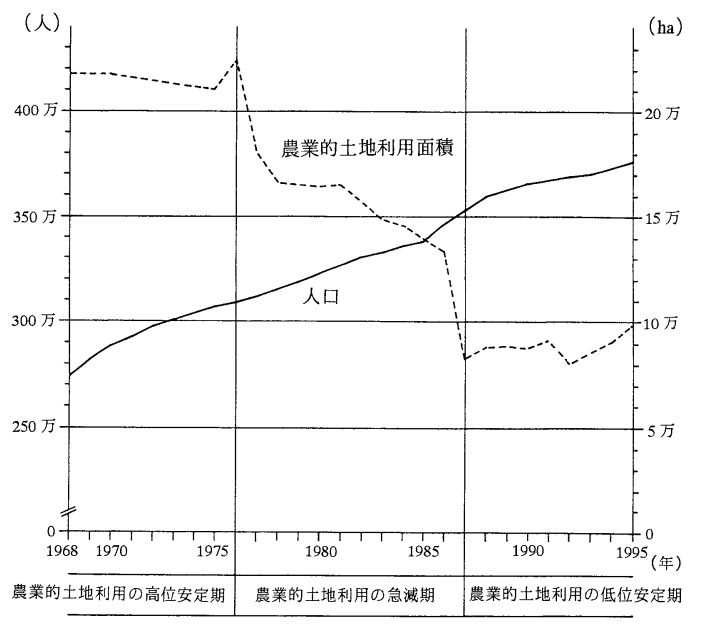

図 4 シドニー都市圈における人口と農業的土地利 用の推移.

(Local Statistics of New South Wales と Regional Statistics of New South Wales に より作成)

Fig. 4 Changes of population and agricultural land use in the Sydney metropolitan region.

土地利用が維持されていた。これは，森林やアー バンブッシュなどの未利用地がシドニー都市圈の 都心に近接して多く残存し，それらの一部を都市 的土地利用に転換することで 1976 年までの流入 人口のほとんどを吸収できていたことを反映して いる (Department of Planning, 1995 ; Young, 2000)。

高位安定期における農業的土地利用の分布パ ターンを検討するため, 1968 年におけるシドニー 都市圈の農業的土地利用の割合を地区（市郡）別 に図 5 に示した。これによれば，シドニー都市圈 の中心業務地区 (ハーバーブリッジの南側の地区) から約 $20 \mathrm{~km}$ の圈域では, 農業的土地利用率（農 業的土地利用面積/地区面積 $\times 100 ） は 1 \%$ 未満 と低く, $20 \mathrm{~km}$ から $60 \mathrm{~km}$ の圈域になると $15 \%$ 以上と高くなり, さらにその外側で $15 \%$ 未満と低 くなる。このような圈構造に類似した農業的土地 利用率の分布パターンは, 都市化の影響が都市中 心部からの距離と地形条件に応じて各地区に一様 に伝わったことを反映したものであった。特に， 
シドニー都市圈は西側をブルーマウンテンズで区 切られた海岸平野に展開しており, 孤立国に近似 した土地空間がつくりだされていたことも農業的 土地利用率の圈構造的な分布パターンが形成され る原因の 1 つになった。また, シドニー平野では 農業的土地利用率が高く, 山地で農業的土地利用 率が低いなど, 地形条件も農業的土地利用率の分 布パターンに少なからず影響を与えていた。しか し, それらは農業的土地利用の圈構造のパターン を歪めるまでのものではなかった。

農業的土地利用の急減期になると, シドニー都 市圈の農業的土地利用の面積は 10 年間で 10 万 ha 以上縮小し, 1987 年の農業的土地利用の面積は約 8 万 haになった。このような農業的土地利用の急 減は, 農業的土地利用の収益性の低下と都市的土 地利用の収益性の拡大, および都市圈の人口増加 に起因していた。特に, 人口増加は土地利用変化 に大きな影響を与えた。1970 年代後半には, 中国 人や東南アジアの人々の移民が急増するようにな り，その多くはシドニー中心部に居住するように なった。流入した移民人口によって押し出され， 郊外に移動した都市人口を吸収するため, 市街地 に隣接した森林や荒地が都市的土地利用に転換さ れた。しかし，それだけでは間に合わず，一部の 農業的土地利用も都市的土地利用に転換されるよ うになった。また，国内における人口移動もシド ニーやメルボルンなどの主要大都市に集中する傾 向にあった（Burnley，1982）。実際，1980 年代 のシドニーとメルボルンにおける国内からの流入 人口はそれぞれ人口増加の約 $20 \%$ と約 $10 \%$ を占 め，それらの割合はブリスベンゃアデレードや パースにおける国内からの流入人口の割合を倰駕 していた ${ }^{4)}$ このような流入人口の多くは農業的土 地利用を都市的土地利用に転換することで収容さ れ, 都市の近郊や周辺農村における農業的土地利 用の縮小傾向が決定づけられた（Newton and Bell, 1996)。

急滅期におけるシドニー都市圈の農業的土地利 用分布パターンを検討するため, 1984 年の農業的 土地利用の割合を地区別に図 6 に示した。これを 概観すると，農業的土地利用率の分布パターンは

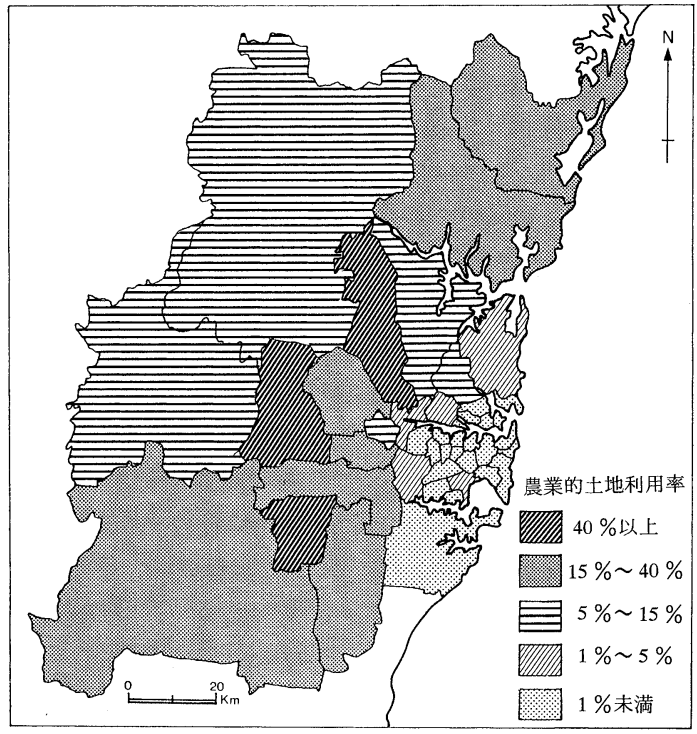

図 5 シドニー都市圈における地区別の農業的土地 利用の割合（1968 年）.

(Local Statistics of New South Wales と Regional Statistics of New South Wales に より作成)

Fig. 5 The rate of agricultural land use by local government area in the Sydney metropolitan region (1968).

圈的な構造からセクター的な構造に変化したこと がわかる。つまり, 都市中心部から $20 \mathrm{~km}$ の圈域 における農業的土地利用率は $1 \%$ 未満で 1968 年 のものと変わりないが，その圈域から北や北西， および南方向のセクターにおける農業的土地利用 率は概ね $5 \%$ 以上 $15 \%$ 未満で，1968 年のものと 比較して低下する傾向を強くしている。これらの セクターに対して, 南西方向のセクターでは農業 的土地利用率は $15 \%$ 以上と高位安定期のものと 変わらず，農業的土地利用は維持されていた。全 体的にみると，ニューカッスルーシドニーーウロン ゴングのコナーベーションに関連するセクターで は，工業発展にともなう農業的土地利用の縮小傾 向が目立っていた。

このようなセクター構造は工業化や都市化の発 展方向だけでなく, シドニー都市圈の地形条件も 大きく反映している（図 1 )。肥沃な土壤と平坦な 


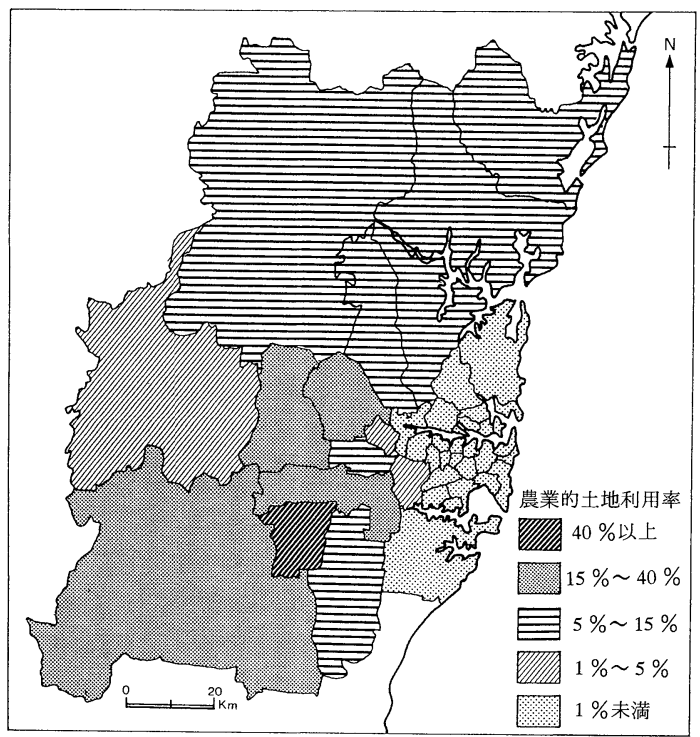

図 6 シドニー都市圏における地区別の農業的土地 利用の割合 (1984 年).

(Local Statistics of New South Wales $と$ Regional Statistics of New South Wales に より作成)

Fig. 6 The rate of agricultural land use by local government area in the Sydney metropolitan region (1984).

土地の広がりはシドニー平野を中心に南西セク ターに展開し，そこでの農業的土地利用は基本的 に維持されていた。しかし，北西部や南部に広が る波浪状の低丘陵地では, 北向きの陽当たり良好 な傾斜地を住宅適地とするオーストラリアの人々 の嗜好性を反映して, 農業的土地利用は宅地開発 とともに縮小する傾向にあった。さらに, 都市中 心部から西に向かう国道 32 号や郊外鉄道に沿っ た地区でも, 農業的土地利用率は都心までの交通 ネットワークの頻度と近接性の高まりを反映して 減少する傾向にあった。例えば, 国道 32 号沿いに 位置するペンリス市では, 都心までの郊外電車の 頻度が 1970 年の 1 時間に 2 本から 1980 年の 4 本 に増加したことにより, 農業的土地利用率が 1970 年の約 $45 \%$ から 1980 年の約 $20 \%$ に急減した。し たがって, 農業的土地利用の分布に関するセク ター構造は工業化や都市化の方向性, あるいは地 形条件とともに, 交通ネットワークの発達によっ

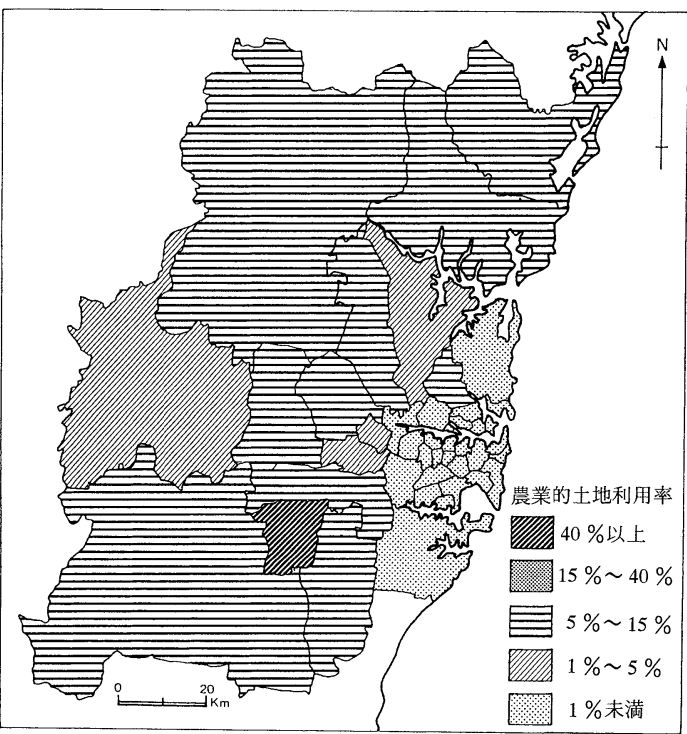

図 7 シドニー都市圈における地区別の農業的土地 利用の割合（1995 年).

(Local Statistics of New South Wales と

Regional Statistics of New South Wales に より作成)

Fig. 7 The rate of agricultural land use by local government area in the Sydney metropolitan region (1995).

てもつくりだされたといえる。

急減傾向にあった農業的土地利用の面積は 1988 年以降, 8 万 ha から 10 万 ha と低位で増減 が繰り返されたが，次第に安定して維持されるよ うになった。この背景には, 農業的土地利用の低 位安定期におけるシドニー都市圈の人口増加率が 年 $0.7 \%$ と急減期の年 $1.4 \%$ と比べて小さくなり, 人口増加による都市的土地利用の需要が相対的に 減少したことがあげられる。シドニー都市圈の人 口が増加傾向から漸増傾向に転じたことは，国内 における人口移動の主要な対象地が年間を通じて 温暖で快適な居住環境をもつブリスベンなどに変 化したことや，シドニーに比較的集中していた移 民人口が国内の他の大都市に分散するようになっ たことなども反映している（Newton and Bell, 1996）。1990 年代以降, 東海岸のブリスベン・シ ドニー・キャンベラ・メルボルン・アデレード都 市圈に居住する人口はオーストラリアの総人口の 
表 1 シドニー都市圈における農業的土地利用変化の諸類型.

Table 1 Types of agricultural land use changes in the Sydney metropolitan region.

\begin{tabular}{|c|c|c|c|c|}
\hline${ }_{1984-1995}^{1968-1984}$ & \multicolumn{2}{|c|}{ 低位安定 } & 高位から低位への変化 & 高位維持 \\
\hline 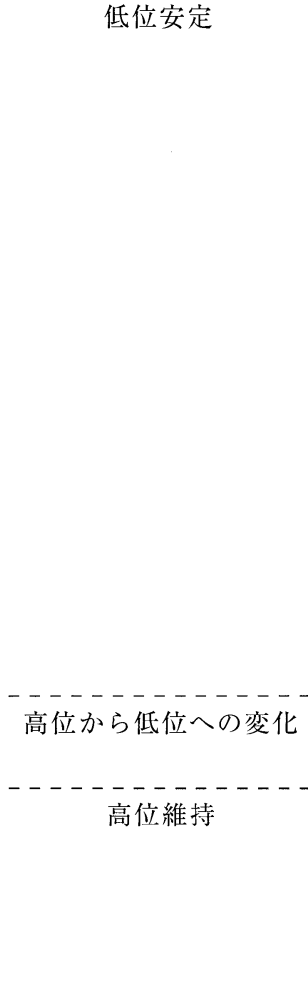 & $\begin{array}{l}\text { Ashifield } \\
\text { Auburn } \\
\text { Bankstown } \\
\text { Blue Mt. } \\
\text { Botany } \\
\text { Burwood } \\
\text { Cantcrbury } \\
\text { Concord } \\
\text { Drummoyne } \\
\text { Hawkesbury } \\
\text { Holroyd } \\
\text { Hornsby } \\
\text { Huntcr's Hill } \\
\text { Hurstvill } \\
\text { Kogarah } \\
\text { Ku-ring-gai } \\
\text { Lane cove } \\
\text { Leichhardt } \\
-------~\end{array}$ & $\begin{array}{l}\text { Manly } \\
\text { Marrickville } \\
\text { Mosman } \\
\text { North Sydney } \\
\text { Parramatta } \\
\text { Randwick } \\
\text { Rockdale } \\
\text { Ryde } \\
\text { Strathfield } \\
\text { Sutherland } \\
\text { Sydney } \\
\text { Warringah } \\
\text { Waverley } \\
\text { Willoughby } \\
\text { Woollahra }\end{array}$ & $\begin{array}{l}\text { Camphelltown } \\
\text { Fairfield } \\
\text { Gosford }\end{array}$ & $\begin{array}{l}\text { Liverpool } \\
\text { Wyong } \\
\text { Baulkham Hills } \\
\text { Blacktown } \\
\text { Camden } \\
\text { Penrith } \\
\text { Wollondilly }\end{array}$ \\
\hline
\end{tabular}

(Local Statistics of New South Wales と Regional Statistics of New South Wales により作成)

約 $75 \%$ に達し, 人口がシドニー以外の主要都市に 集中するようになってきた。さらに, 土地利用ゾー ニングによってグリーンベルトが設定され，農村 域における都市的土地利用の侵入が一部の地区を 除いて抑制されたことも，農業的土地利用の面積 が低位安定の方向で推移するようになった理由の 1つであった。

低位安定期における農業的土地利用の分布を検 討するため, 1995 年における地区別の農業的土地 利用の割合を図 7 に示した。これによれば，シド ニー都市圈における農業的土地利用の基本的な分 布は，農業的土地利用率が低い都市中心部から約 $20 \mathrm{~km}$ 圈と, その外側の農業的土地利用率が相対 的に高い圈域とで特徵づけられる圈構造を再び呈
するようになった。このような圈構造は土地利用 ゾーニングによって計画的につくりだされたもの である。しかし部分的には, 農業的土地利用率の 低い地区が都市中心部から幹線交通ネットワーク に沿ってセクター状に伸びていることや，農業的 土地利用率の高い地区が島状に点在していること など，農業的土地利用率の分布に関する圈構造は 交通ネットワークや地形条件によって歪められる 傾向にあった。

\section{2）農業的土地利用変化の地域類型}

次に，農業的土地利用率の動向を地区別にみる と，農業的土地利用変化には地域的差異があるこ ともわかる。このような地域的差異を検討するた め, 農業的土地利用変化の地域類型を明らかにし 


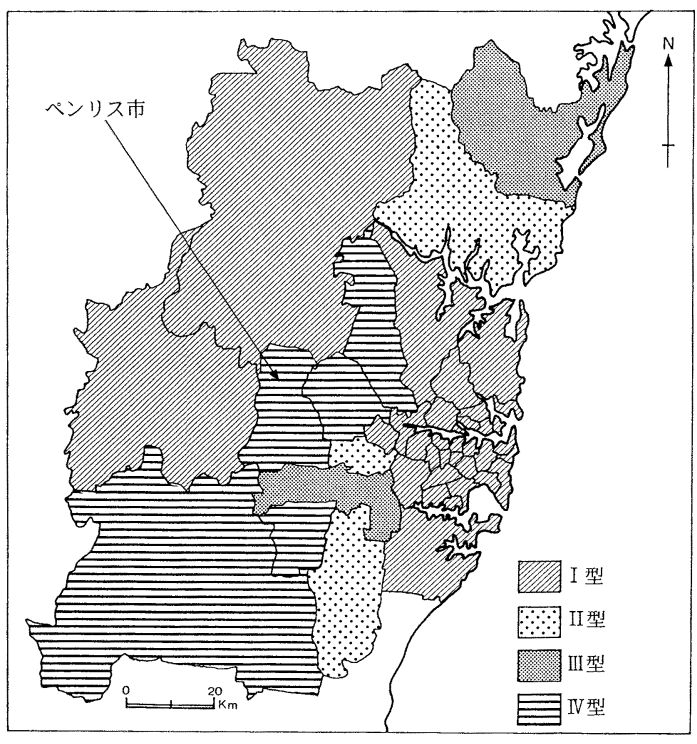

図 8 シドニー都市圈における農業的土地利用変化 の地域類型.

(Local Statistics of New South Wales と Regional Statistics of New South Wales に より作成)

Fig. 8 Regional types of agricultural land use changes in the Sydney metropolitan region.

た。最初に, 1968 年から 1984 年の, および 1984 年から 1995 年の地区別の農業的土地利用率から それらの変化を求め，3つにタイプ分けした。第 1 の変化タイプは 2 時点の農業的土地利用率がと もに低位 (平均未満) のままのもの ${ }^{5}$, 第 2 の変 化夕イプは高位（平均以上）から低位に変化した もの, 第 3 の変化夕イプは高位のレベルを維持し ているものである。次に, 農業的土地利用の変化 タイプに基づいて，1968 年から 1984 年，および 1984 年から 1995 年における地区別の農業的土地 利用の変化タイプをクロスさせて表 1 に整理し, シドニー都市圈における農業的土地利用変化を 4 つの地域類型にまとめた。それらは低位安定型 ( I 型), 高位から低位安定への変化型（II 型）, 高位 安定から低位への変化型 (III型), 高位維持型 (IV 型）の 4 つである。

I 型は農業的土地利用率の増減が小さく繰り返 されているが，いずれの時期においても低位のま
ま推移してきた地区である。II 型は 1968 年から 1984 年にかけて農業的土地利用率が高位から低 位に変化し, その後は低位のまま, ほぼ安定して 推移してきた地区である。同様に，III型の地区も 1984 年から 1995 年にかけて農業的土地利用率が 高位安定から低位に変化し, その後は低位のまま 推移してきた地区である。他方， $\mathrm{N}$ 型は農業的土 地利用が 1968 年以降一貫して高位のまま推移し, 高位の状態が維持されてきた地区である。図 8 は シドニー都市圈にける農業的土地利用変化の地域 類型の空間的な分布を示している。これによれば, 農業的土地利用変化の地域類型の分布は概ね圈構 造のパターンを呈して分布しているが, 都市周辺 ではセクター構造の様相も呈していた。つまり, 都市中心地とその近郊では I 型がまとまって, そ の外側の都市周辺にはII型と III型, およびI $\mathrm{N}$ 型が 混在して分布しており, 都市圈周縁の後背農村で は I 型が II ・ II ・ I 型の混在地域を取り囲むよう に再び分布している。また, 地域類型の混在地域 では, IV 型が沖積低地や農業適地と関連してセク ター状に展開する傾向もみられた。

このような分布パターンでは, シドニー都市圈 の地形条件と都市中心地への近接性が基本的に反 映されており, 都市の中心部と近郊, および山地 が展開する後背農村では I 型が卓越し, 平地や低 丘陵地が展開する都市周辺では II ・ II ・ IV 型の混 在がみられた。しかし、これら 3 つの地域類型の 混在は地形条件と都市中心部への近接性だけでは 説明することができず，シドニー都市圈における 土地利用計画や土地利用の競合の程度なども重要 な条件になっている。シドニー都市圈の中心部か ら南北や東西に走る幹線道路沿いでは, 土地利用 の激しい競合の結果, 農業的土地利用から都市的 土地利用への変化が景観的にも機能的にもいち早 く認められ, 農業的土地利用の縮小が決定づけら れた。その一方で, 農業適地が土地利用計画で保 全され, 農業的土地利用がセクター状ないし島状 に残される傾向にもある。

複数の地域類型が混在する圈域のなかで, 農業 的土地利用と都市的土地利用との競合が著しいの はIV 型の地域で, 農業的土地利用率が比較的高位 
で維持されているが，その割合の低下は都市的土 地利用の侵入が激しくなるにつれて目立っている。 例えば，シドニー都市圈西郊のペンリス市では農 業的土地利用率は高位で維持されているが, 1968 年の $50 \%$ から 1995 年の $14 \%$ と著しく低下してお り, その変化の大きさはシドニー都市圈でも最大 である。そのため, 本研究ではシドニー都市圈に おける農業的土地利用変化を検討する事例地区と してペンリス市を抽出した。以下ではペンリス市 キャスルレイ地区の現地調查に基づいて，農業的 土地利用変化を検討する。

\section{IV. ペンリス市キャスルレイ地区に おける土地利用}

\section{1）土地利用の存立基盤}

ペンリス市はシドニー中心地から西へ直線距離 で約 $60 \mathrm{~km}$ の, 時間距離にすると通勤電車で約 1 時間の位置にある。ペンリス市の人口は 1995 年 現在で約 18 万で, 1985 年から 1995 年まで 10 年 間で約 5 万人増加しており, その人口増加率はシ ドニー都市圈において最も高い值になっている ${ }^{6)}$ 特に, シドニー中心部への近接性が鉄道網の発達 や高速化で高くなり, 都心への通勤者の世帯が 1985 年以降多く居住するようになった。そのため, 通勤者用の一戸建て持ち家住宅の建設が進み,

1985 年から 1995 年までの 10 年間で 10,934 戸の 一戸建て住宅が建設された。さらに, 1992 年には 200 の専門店と $6 つ$ の゙パートで構成される ショッピングセンターが建設され, ペンリス市は シドニー都市圈の周辺中心地としての地位を確か なものにした。このように, ペンリス市はシド ニー中心部の衛星都市としての性格を強くしてい るが，もともとはシドニー平野を基盤とする農業 地域のサービス中心地として発達した都市であっ た。

ペンリス市は肥沃なシドニー平野の西部に位置 し, 19 世紀初頭にヨーロッパ人の入植が農業適地 のキャスルレイ地区（ペンリス市の北西部）やム ルゴア地区（ペンリス市南西部）を中心に進めら れた。1863 年にシドニー中心部までの鉄道が敷設 され，都市域への近接性が高まるにつれて，ペン
リス市は都市住民に新鮮な農産物を供給する食料 基地としての役割を担うようになった。特に, 飲 用牛乳が腐敗しにくい輸送距離にあることを反映 して，ペンリス市は市乳を大量にシドニー都市圈 に供給するようになった。そのため，ペンリス市 は都市住民に近郊酪農地域として周知されるよう になった。さらに，1867 年にはニピーアン・ホー クスベリー川に鉄橋が架けられ，鉄道網がブルー マウンテンズを越えて内陸部に通じるようになっ た。その結果, ペンリス市は内陸部からの農産物 の集散地となり, 小麦や羊毛などの農産物の加工 工場が多く立地するようになった。現在でも，乳 業工場や製粉工場，パン工場，酒醸造工場などの 農産物の加工工場が立地している。

以下では，ペンリス市に扔ける伝統的な農業地 域の 1 つであるキャスルレイ地区を対象に, 1984 年と 1997 年の土地利用図を作成し, 農業的土地利 用変化を検討する。1984 年の土地利用図は空中 写真の判読と聞き取り調查に基づいて当時の土地 利用を復原したものであり，1997 年の土地利用 図は現地調査により作成したものである。

\section{2） 1984 年の土地利用}

ペンリス市キャスルレイ地区における1984 年 の土地利用を図 9 に示した。これによれば，キャ スルレイ地区の土地はニピーアン川の沖積低地と 低丘陵地から構成されている。これらの地形条件 を反映して，地区の土地利用は農業的土地利用が 広がる沖積低地と林地や荒地が広がる低丘陵地と に概ね大別できる。しかし，低丘陵地を開発して 農業的土地利用が広がっているところや住宅地が 造成されているところ，あるいは野生の動植物を 保護するために林地や荒地のままになっている沖 積低地もある。また，沖積低地の一部には砂利の 採石場が立地し, 都市中心部への近接性を活かし て砂や小石などの資材を住宅やビルの建設に供給 している。

全体的には, 都市的土地利用の拡大は目立たな いが，地区がペンリス駅に隣接していることを反 映して, 都市的土地利用が地区南部を中心に広が りをみせている。この都市的土地利用の多くは, 林地や荒地を開発して建設された住宅地である。 


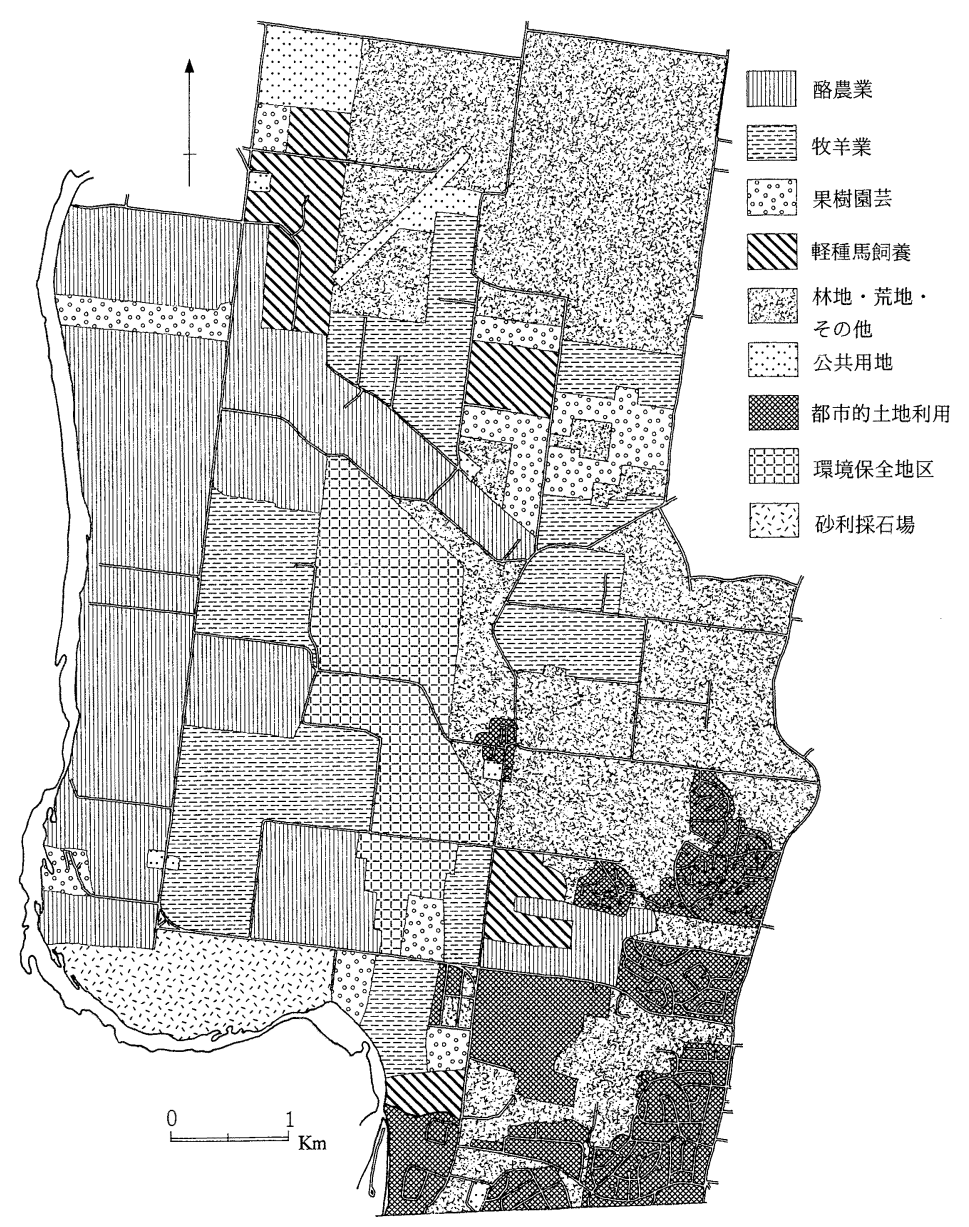

図 9 ペンリス市キャスルレイ地区における土地利用（1984 年）. (空中写真と聞き取り調査により作成)

Fig. 9 Land use in Castlereagh area, Penrith City (1984).

地区南部の住宅地は既存の住宅地に連続して拡大 する傾向よりも，林地や荒地に点在し虫食い状に 広がる傾向を示している。これは，林地や荒地が 開発に必要な土地をまとまって提供したことや, それらにおける住宅地の開発が都市計画で奨励さ れたこと,さらに住宅開発が丘陵地の緩斜面や林 地を借景にして，北向き斜面を中心にして選択的 に建設されたことに起因している。また，地区南 部の幹線道路沿いでは, 鉄道や駅に近接している 利点を活かして, 機械工業や電子工業の工場誘致 が行われ ${ }^{7)}$, 工場立地にともなう都市的土地利用の 拡大もみられた。このように，都市的土地利用の
拡大が鉄道沿線や駅周辺を中心にして局所的にみ られたが，キャスルレイ地区の多くの土地では農 業的土地利用が維持されていた。

1984 年におけるキャスルレイ地区の農業的土 地利用では, 酪農業や牧羊業, 果樹園芸, 軽種馬 飼養が比較的多くみられた。そのなかでも, 酪農 業が中心的な土地利用であり, 主にニピーアン川 に沿った沖積低地に分布していた。キャスルレイ 地区では温暖な気候条件と肥沃な土壤条件を反映 して, 1 ha 当たりの 1 日の牧草生産量は乾燥重量 で $10 \mathrm{~kg}$ 以上であり, その生産量が年間を通じて 維持されている。これは, 1 ha で 1 頭の乳牛を周 
年放牧で飼養できることを示しており，牧草の生 産性の高さとその牧草の周年的で効率的な利用が キャスルレイ地区の近郊酪農を支えてきた。実際, この地区の酪農家は平均で約 $70 \mathrm{ha}$ の牧草地を所 有し, それを 7 ないし 8 の牧区に区分して, 70 頭 前後の乳牛を周年的に輪換放牧することで牧草の 効率的な利用を図ってきた ${ }^{8)}$ 。したがって, 舎飼用 の牛舎がまったくなく, 搾乳舎, 機械庫, 乾草譻 蔵庫, バンカーサイロなどの施設からなる酪農場 と, 農家住宅を中心に広がる牧草地をいくつかの 牧区に区分する牧柵の存在は, キャスルレイ地区 の特徵的な農村景観になっていたといえる。

酪農業に次いで空間的な広がりをもつ農業的土 地利用は牧羊業であった。牧羊業も酪農業と同じ ようにニピーアン川の沖積低地を中心に立地して いたが，その分布パターンは酪農場の広がりのな かに島状に点在するものであった。牧羊農場の規 模は平均で約 $60 \mathrm{ha}$ と酪農場とほとんど変わらず, 農場景観も酪農施設やよく手入れされた牧柵など がないことを除けば，多くの点で類似していた。 これは, 牧羊農場の多くが酪農場から転換したも のであり，その転換は農業従事者の高齢化や兼業 化による労働力の不足で酪農業を継続することが できなかったことに起因していた。実際, 1984 年 における 1 農場当たりの農業労㗢力は酪農場で約 1.8 人, 牧羊農場で 0.8 人であり, 農業労働力の平 均年齢も酪農場で 40 歳代半ば, 牧羊農場で 50 歳 代後半であった。したがって, 牧羊農場は酪農場 に比べて労働粗放的に経営されていたといえる。 また, かつての酪農場が果樹園芸農場や軽種馬飼 養農場に転換されたものもいくつかあり, それら は林地や荒地に, あるいは都市的土地利用に隣接 して分布していた。しかし，それらの件数は少な く, 分布も小規模に分散して面的な広がりをもつ までにはいたっていなかった。

\section{3） 1997 年の土地利用}

1997 年におけるペンリス市キャスルレイ地区 の土地利用を示した図 10 によれば, その土地利用 の様相は 1984 年のものから大きく変化した。都市 的土地利用は住宅地と工業団地, および公共用地 を中心に拡大した。かつて飛地的に立地していた
住宅地では, 住宅地と住宅地の間に存在した林地 や荒地も住宅地として開発され, 住宅地が市街地 と連続するようになった。同時に, 住宅地の建設 は残された林地や荒地でも進み，住宅地の新たな 島状の飛地的な分布が 1984 年当時の農業的土地 利用の領域にもみられるようになった。工業団地 も幹線道路に沿って拡大し，それは市街地に連続 する都市的土地利用として明確に識別できるよう になった。このような工業団地は従来，林地や荒 地の転換で建設されていたが, 1990 年以降にな ると工場団地は農地を転換して建設されるように もなった。さらに, 1997 年のキャスルレイ地区 の都市的土地利用において特徵的なことは, 公共 用地が農地を転用して広く展開していることであ る。この公共用地の大きな広がりはペンリス湖計 画で建設された人造湖で ${ }^{9}$, シドニーの都市住民 の親水空間やボート遊びの余暇空間として利用さ れるだけでなく，シドニーオリンピックのボート とカヌー競技会場としても利用された。

1997 年におけるキャスルレイ地区の土地利用 では，都市的土地利用の拡大が目立っていたが， 実際の農業的土地利用の面積は, 1984 年の土地 利用図と比較して 4 分の 3 ほどに減少したにすぎ なかった。しかし, 酪農業と牧羊業の土地利用が 明らかに縮小し, それらの面積は 1984 年のものの $50 \%$ 以下になった。酪農場と牧羊農場の土地利用 の立地が沖積低地を中心としていることは従来と 変わりないが，それらの分布パターンは島状で分 散的なものになる傾向にある。キャスルレイ地区 における 1997 年の農場経営を整理した表 2 によ れば, 酪農場は 7 つり, それらの規模は $70 \mathrm{ha}$ から 100 ha で, それぞれ夫婦 2 人で経営されてい る(口絵 2-1)。酪農場はそれぞれ 100 頭から 120 頭の搾乳牛を飼養し, 生産割当 (クォー夕) 制度 に基づいて市乳生産を行っている ${ }^{10)}$ 。しかし，ど の酪農場も牧草地の面積が縮小し, 牧草の生産量 を上回って搾乳牛を飼養するようになったため, 冬季には内陸部の畑作農場から穀物飼料を購入し ている。牧羊農場は 3 つあり（表 2 ），その規模は 50 ha から 100 haで, 主に農場主が牧畜の担い手 になっている。牧羊農場では平均して約 300 頭の 


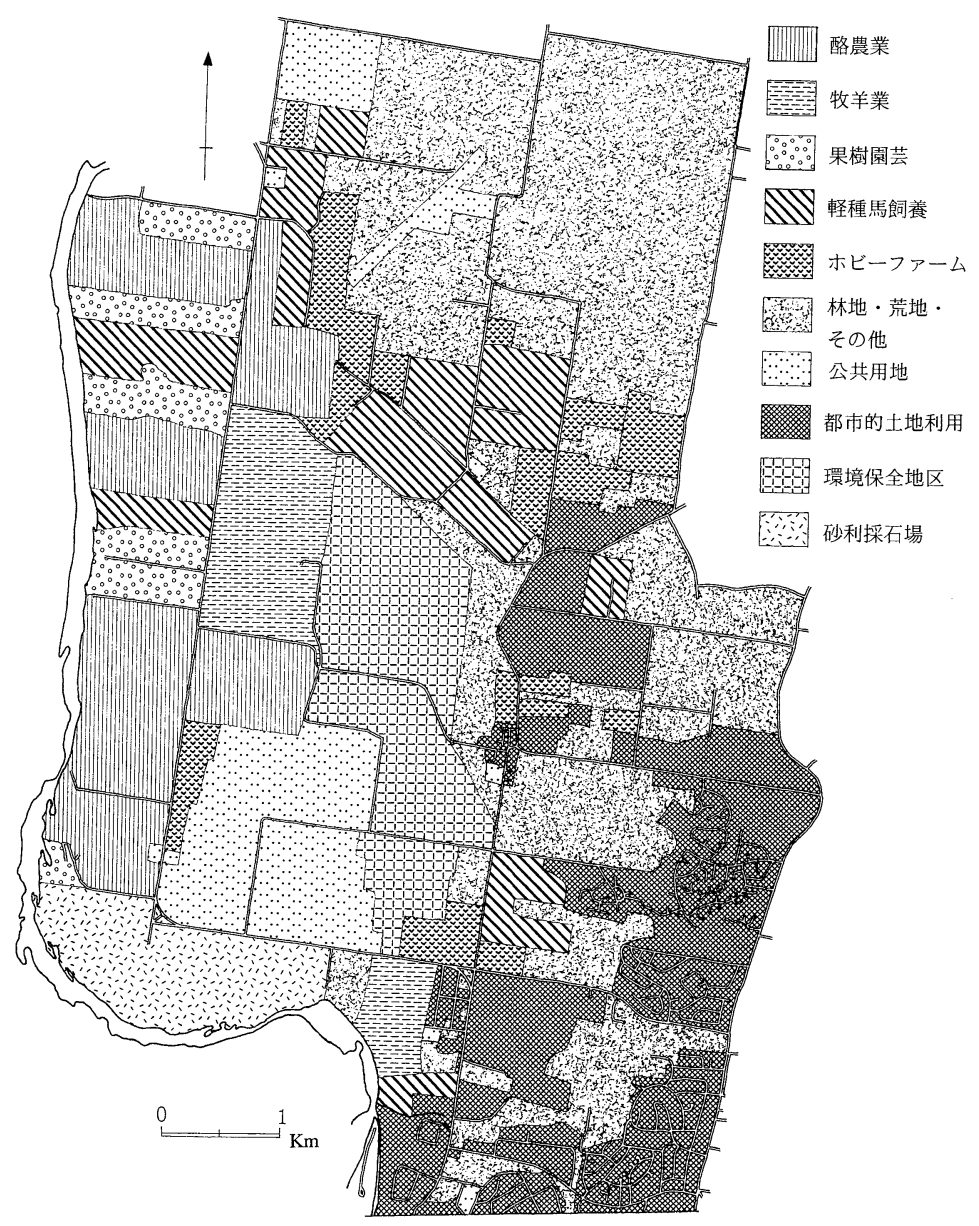

図 10 ペンリス市キャスルレイ地区における土地利用（1997 年). (現地調查により作成)

Fig. 10 Land use in Castlereagh area, Penrith City (1997).

羊と約 50 頭の肉用乳牛が放牧され，その経営は労 働力の面でも土地利用の面でも粗放的である。

酪農業や牧羊業とは反対に, 農業的土地利用が 拡大傾向にあるのは園芸農業と軽種馬飼養である。 これらの土地利用は都市的土地利用に隣接して分 布するとともに，土地の細分化と収益性の拡大を 反映して ${ }^{11)}$, 酪農場が広がっていた沖積低地にも 点在するようになった。園芸農場は $6 つ$ つ（表 2), その規模は 50 ha から 70 ha で，農場主夫婦 と雇用労働者 1 人が農業の担い手になっている。 園芸農場では，ジャガイモ・キャベッ・タマネギ・
ニンジンなどが 1 年 2 作で生産され, 野菜栽培は 市場の需要に応じた少品目大量生産と, 牧畜より も集約的な土地利用で特徴づけることができる。 また，園芸農場のうち 3 つは中国系オーストラリ ア人によって経営されており, シドニーの多文化 社会の需要に応じて, 中国野菜が多く生産されて いる。

他方, 軽種馬農場は 15 と多く（表 2), その規 模は 50 ha から 70 ha で, 農場主夫婦と雇用労働 者 2 人が経営に従事している。軽種馬農場では, 10 頭から 20 頭のサラブレッドが飼養され, サラブ 
表 2 ペンリス市キャスルレイ地区における農場の夕イプとその特徵（1997 年）.

Table 2 Farm types and their characteristics in Castlereagh area, Penrith City.

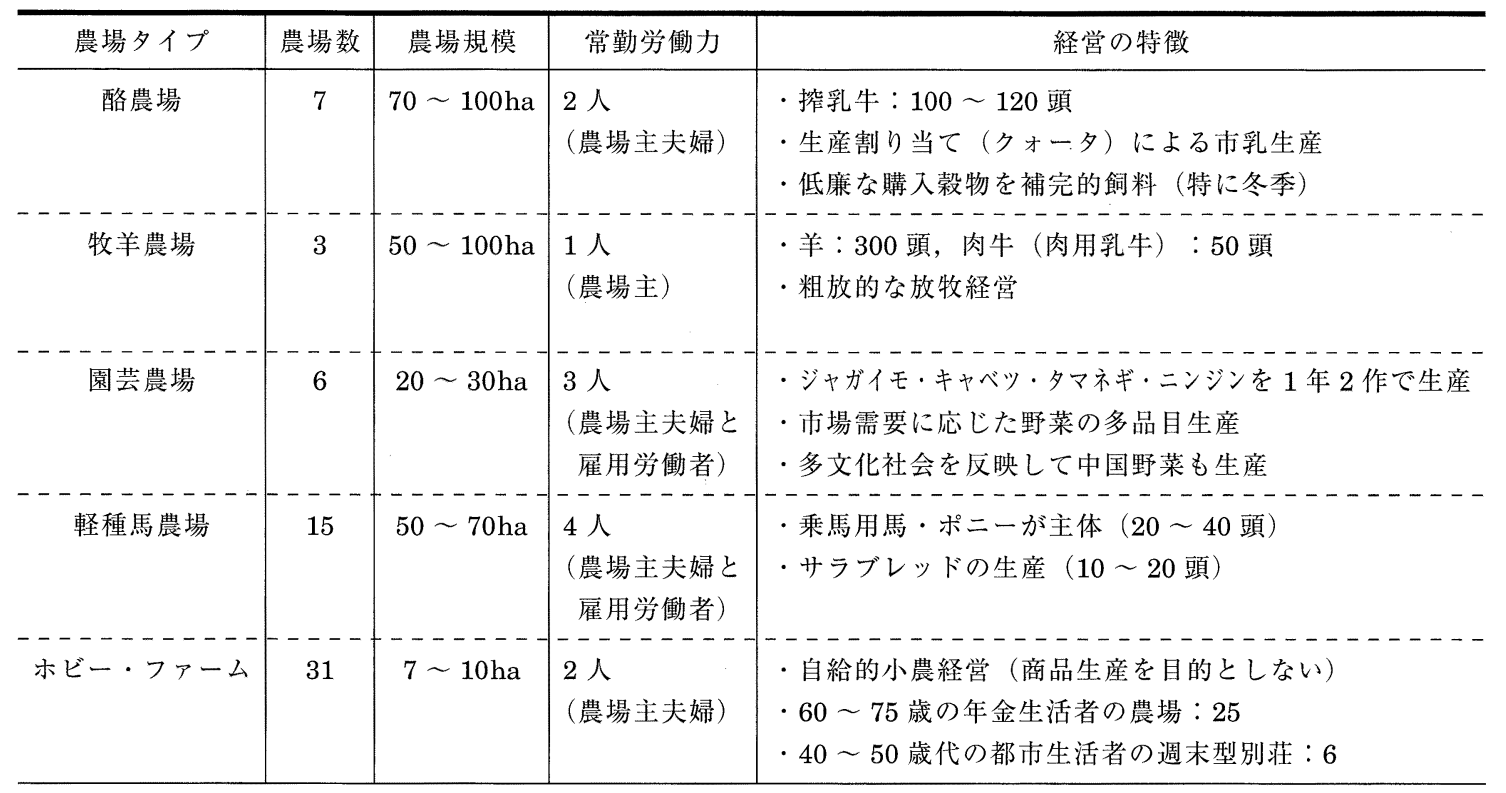

（聞き取り調查により作成）

レッドの販売で得られる収入は 1997 年現在で 1 頭当たり約 1 万 8,000 オーストラリアドル（1997 年現在で約 162 万円）である。そのため，軽種馬 農場の年間収入は平均で約 20 万オーストラリア ドル（1997 年現在で約 1,800 万円）で, 酪農場と 園芸農場のそれの約 3 倍と約 2 倍にそれぞれ相当 している。さらに, 軽種馬農場では, 20 頭から 40 頭の乗馬用馬とポニーが放牧されており，それら は週末に乗馬を楽しむ都市住民から預託されてい るものである（口絵 2-2）。

1997 年におけるキャスルレイ地区の土地利用 では, ホビーファームが農業的土地利用として新 たにみられるようになった。ホビーファームは林 地や荒地, あるいは都市的土地利用に隣接して低 丘陵地を中心に分布し, 沖積低地における分布は 少ない。沖積低地は農業適地であるため, そこで は高収益性の園芸農業や，あるいは土地利用型の 牧畜業が立地する傾向にある。ホビーファーム数 は 31 とキャスルレイ地区で最も多い農場夕イプ であり, その規模は 7 ha から 10 ha で, 一般には 夫婦 2 人が農業に従事している。ホビーファーム
の大きな特徵は商品生産を目的としていない農牧 業を営んでいることで, その経営形態は主に自給 的な小農複合経営になっている。つまり, 自給的 な小農複合経営は多品目少量生産の野菜栽培や果 樹栽培，あるいはさまざまな種類の牧畜業など多 様な経営部門を少しずつ組み合わせている。この ような複合経営は年間の農業労働の平準化と, 多 様で飽きのこない農作業を配慮したものになって いる。ホビーファームの経営者を年齢別にみると， 60 歳から 75 歳までの年金生活者が 25 人と多く, 残り 6 人は 40 歳代と 50 歳代の都市居住者である。 年金生活者は生きがいとしてホビーファームを経 営し, 都市居住者は週末型の別荘や余层の場とし てホビーファームを利用してる（口絵 2-3）。

\section{V. ペンリス市キャスルレイ地区の農業的 土地利用変化とその持続的性格}

キャスルレイ地区における 1984 年と 1997 年の 農業的土地利用の変化を詳細に検討するため表 3 を作成した。表 3 はキャスルレイ地区の土地利用 図に基づいて 1984 年における個々の農場の土地 
表 3 ペンリス市キャスルレイ区における農業的土地利用と土地区画の変化.

Table 3 Changes of agricultural land use and land division in Castlereagh area, Penrith City.

\begin{tabular}{|c|c|c|c|c|c|}
\hline${ }_{1997} 1984$ & 酪農 & 牧羊業 & 園芸農業 & 軽種馬飼養 & 計 \\
\hline 酪農 & $6.4(7)$ & & & & $6.4(7)$ \\
\hline 牧羊業 & $1.0(1)$ & $2.0 \quad(2)$ & & & $3.0(3)$ \\
\hline 園芸農業 & $1.5(4)$ & & $2.0(2)$ & & $3.5(6)$ \\
\hline 軽種馬飼養 & $1.6(4)$ & $0.8(2)$ & 1.0 (1) & $7.8(8)$ & $11.2(15)$ \\
\hline ホビーファーム & $0.4(2)$ & $1.1(7)$ & $5.3(13)$ & $0.8 \quad(4)$ & $7.6(31)$ \\
\hline 林地・荒地 - その他 & 1.1 & 2.7 & 2.4 & 0.4 & 6.6 \\
\hline 公共用地 & 1.0 & 1.8 & 0.3 & & 3.1 \\
\hline 都市的土地利用 & & 2.6 & & & 2.6 \\
\hline 計 & 13.0 & 11.0 & 11.0 & 9.0 & $44.0 \quad(62)$ \\
\hline
\end{tabular}

数字は 1984 年のそれぞれの農場の土地区画を 1 とし，その相対的な值の合計を示している．また， （）内の数字は 1997 年の経営タイプ別の農場数を示す。（土地利用図と聞き取り調査により作成）

区画を 1 区画として，1997年の農場の土地区画を その相対的な值で示してある。例えば 1984 年にお いて，ある酪農場が 1 つまとまりとして土地を 所有していれば，その土地区画を 1 区画とし，そ れが 1997 年においても継続して利用されていれ ば, 1997 年の土地区画も 1 区画として数えること ができる ${ }^{12)}$ 。もし，その土地の $70 \%$ と $30 \%$ の面 積が 1997 年にそれぞれ軽種馬飼養農場と園芸農 場に転換されたならば，軽種馬農場と園芸農場の 土地区画は 1984 年との相対的な值で示し, 転換し た土地面積に比例させて 0.7 区画と 0.3 区画とな る。1997 年の土地区画を 1984 年との相対的な值 で示すことは, 都市近郊や都市周辺の農村で顕在 化している土地の細分化を理解しやすいものにし ている。このようにして土地区画の変化を表 3 で 検討すると, 酪農場の土地は 1984 年で 13.0 区画 あったが，1997 年では 1984 年の土地の 6.4 区画 が酪農場として残され, 酪農場の土地区画の約半 分が他の農業的土地利用に転換されたことがわか る。また 1997 年では, 1984 年の酪農場の 6.4 の 土地区画に 7 つの酪農場が立地しており, それら の数字は個々の酪農場の規模が縮小していること も示唆している。
1984 年における酪農場の土地は軽種馬飼養農 場と園芸農場, および牧羊農場にもそれぞれ 1.6 区 画と 1.5 区画，1.0 区画ずつ転換された。そのうち, 牧羊農場は 1984 年の酪農場の土地区画をそのま ま転換したものであるが, 軽種馬飼養農場と園芸 農場は 1984 年の 1.6 と 1.5 の土地区画にそれぞれ 4つの農場が立地しており,かつての酪農場の土地 の細分化が行われたことを示している。また，軽 種馬飼養農場は牧羊農場や園芸農場からもそれぞ れ 1984 年の土地区画で 0.8 区画と 1.0 区画転換さ れている。そのうち, 牧羊農場からの転換では 1984 年の土地区画の 0.8 区画に 2 つの軽種馬飼養 農場が立地しており, 牧羊農場の土地の細分化が みられる。園芸農場から軽種馬飼養農場への転換 では，園芸農場の土地区画がもともと小規模であ るため, 農場の土地の細分化がなかった。このよ うな園芸農場から軽種馬飼養農場への転換は, 単 位面積当たりの土地収益性の向上を図ったもので ある。全体的には, 軽種馬飼養農場と園芸農場は 酪農場や牧羊農場のかつての土地区画をそれぞれ 2 分の 1 程度と 3 分の 1 程度に細分化して立地して いる。

土地の細分化によって最も特徴づけられる農場 
立地はホビーファームである。1997 年において， 31 のホビーファームが 1984 年の土地区画の 7.6 区画に立地しており，そのことはかつての土地区 画を 4 分の 1 から 6 分の 1 に細分化して立地して いることを示している。1984 年から 1997 年の土 地利用変化のなかでホビーファームへの転換が多 かったのは牧羊農場と園芸農場で, それぞれ 1984 年の土地区画の 1.1 区画と 5.3 区画が 12 と 13 の ホビーファームに転換された。一般に大都市の近 郊および周辺農村では, 土地集約的な農場経営な いし労働粗放的な農場経営が立地する傾向にあっ た。しかし, ホビーファームは土地集約的でも労 働粗放的でもない農業的土地利用で, 高齢者の生 きがいや都市住民の余㗇などの非経済的な要因に よって立地している。特に, 高齢者が農場経営に 生きがいをもって従事する現象は, プロダクティ ブ・エイジングと呼ばれ, シドニー都市圈の周辺 農村では 1990 年代以降に農業的土地利用を維持 する1つの政策として奨励されてきた（Department of Planning, 1995)。

次に, 農業的土地利用から非農業的土地利用人 の転換をみると（表 3), 荒地への転換が 1984 年 の土地区画で 6.6 区画と比較的多いことがわかる。 このような転換の多くは農牧業を中止した農場が 作付放棄したり，放牧地を荒地化させているもの で, 農場の土地そのものが売り出し中で荒地に なっているものも少なくない。そのため, 他の農 業的土地利用や都市的土地利用に早晚転換される 可能性が高い。また, 公共用地を含めた都市的土 地利用への転換は 1984 年の土地区画の 5.7 区画で あり，そのうち牧羊農場から転換されたものが 1984 年の土地区画の 4.4 区画と相対的に多い。こ れは, 最も粗放的な農業的土地利用が都市的土地 利用に転換されたことを示しており, 大都市の近 郊や周辺農村における農業的土地利用变化として 一般にみられる現象である。しかし, 農業的土地 利用から公共用地を含めた都市的土地利用への転 換が都市周辺農村としては少ないことが，キャス ルレイ地区の大きな特徴になっている。これは, ホビーファームが非経済的な要因で立地すること によって, 農業的土地利用から都市的土地利用へ
の転換が抑制されていることに起因している。

\section{VI. 結 論}

本研究はシドニー都市圈周辺農村における農業 的土地利用変化の持続的性格をペンリス市キャス ルレイ地区を事例にして検討した。ペンリス市は シドニー都市圈の拡大方向の 1 つに位置し, 工業 化や都市化の圧力が高まるにつれて, 農業的土地 利用と都市的土地利用の競合が著しい典型的な都 市周辺農村の地域である。ペンリス市は都市周辺 農村の性格をもちながら, 農業的土地利用を維持 させてきた。このような農業的土地利用の維持は, 農業適地としての土地条件や気候条件, ヨーロッ パ人の入植時から農業地域や農産物の集散地とし て発展してきた歴史的条件，および農産物を供給 する都市市場への近接性とそれを活かした収益性 の高い農業の立地などの社会・経済的条件, さら に市乳割当制度や都市計画による農業地域の保全 などの制度的条件によって支えられてきた。

他方, シドニーの都市中心部への近接性が交通 ネットワークの高速化や大型化によって向上する につれて, あるいは住宅適地として良好な土地条 件を反映して，住宅地や工場用地などの都市的土 地利用はさらに拡大する傾向を強めている。ペン リス市キャスルレイ地区では，このような都市的 土地利用の拡大がホビーファームの成立と発展に よって抑制されてきた。つまり，酪農業や牧羊業 のような伝統的な牧畜業が都市化の進展にとも なって軽種馬飼養や園芸農業のような集約的な農 業に変化し, さらにホビーファームに変化するこ とで, 農業的土地利用が都市的土地利用に変化す ることが抑制されている。ある 1 つの農業的土地 利用がそれと異なる農業的土地利用に変化してい く一連の流れは, 農業的土地利用変化の持続的性 格として特徴づけることができる。このような持 続的性格を生みだすことにおいて，ホビーファー ムは重要な役割を果たしてきた。

ホビーファームは都市的土地利用を抑制し，農 業的土地利用をするだけでなく，農地の荒廃や荒 地化を防ぎ，緑地を確保するなど土地の自然的基 盤の保全に機能している。また，ホビーファーム 
は農村人口や農村コミュニティを維持して地域の 社会・経済的基盤の保全に機能するだけでなく， その担い手の多くが高齢者であることから，高齢 者に生きがいを与える高齢者対策としても機能し ている。さらに，ホビーファームは高齢者や都市 住民の農村生活を通じて，ヨーロッパの農村生活 や文化などの歴史・文化的基盤の保全にも機能し ている。したがって，ホビーファームは土地の自 然的基盤や地域の社会・経済的基盤，あるいは歴 史・文化的基盤を保全し，そのことによって農業 的土地利用変化の持続的性格がもたらされてきた といえる。特に, 高齢者の生きがいや都市生活者 の余暇，および農村生活への郷愁や憧憬といった 非経済的要素が，ホビーファームを支えるととも に, シドニー都市圈周辺農村における農業的土地 利用変化の持続的性格を支えている。

\section{謝 辞}

本研究は東京都在外研究 (1997 年 3 月から 9 月) の 調查に基づいており，資料収集や現地調査の際には，ペ ンリス市キャスルレイ地区の農家の方々にお世話になっ た。また，本稿を作成する際にはシドニー大学地理学教 室の Dr. \& Prof. Robin F. Warner とニューイングラン ド大学の地理学・地域計画教室の Dr. Roger Epps から有 益なアドバイスをいただいた。また，本研究をまとめる に際して, 平成 13 年度文部省科学研究費補助金基盤研 究 (C) (研究代表者, 菊地俊夫) を利用した。ここで, 皆様に深く感謝の意を表します。

本稿の内容は 1998 年度日本地理学会春季学術大会 (国士舘大学)ににおいて発表したものである。

\section{注}

1）オーストラリアでは国勢調査が 5 年ごとに行われ， 最も新しい国勢調查は 1996 年に実施された。国勢調 査や農業センサス，および工業統計や商業統計などの 集計結果は，オーストラリア統計局 (Australian Bureau of Statistics）で管理しており，統計書とし て購入できるほか, インターネット (http://www.abs. gov.au）で閲覧することができる.

2) State Planning Authority of New South Wales (1973) によれば，キャンベルタウンとカムデン，お よびアッピンから成るニュータウン建設は 1951 年に The County of Cumberland Planning Scheme で計 画され，その計画を受け継いだ 1967 年の Sydney Region Outline Plan によって実現された. 計画では, 経済や雇用や社会サービスなどの面で自立した都市を
目差し，3つのニュータウンで人口 50 万の都市を建 設するとしていた。

3）自然植生ないしそれに近い雑木林や灌木林がシド ニー都市圈に残されており，それらはアーバンブッ シュとして, 環境保全や緑地空間としてだけでなく, レクリエーション空間や教育・学術研究の場として重 要な役割を担っている.

4） 1981 年から 1985 年までのシドニー都市圈における 国内からの流入人口は約 3 万であり，それは 1981 年 から 1985 年の人口増加数の約 $20 \%$ 占めていた. 同 様に，シドニー都市圈における国内からの流入人口の 割合を 1971 年から 1975 年までについてみると, そ れは約 $5 \%$ であり，国内からの流入人口の割合が人口 増加とともに上昇した。

5）シドニー都市圈における地区別の農業的土地利用率 の平均は, 1968 年で $17.6 \%, 1984$ 年で $11.8 \%, 1995$ 年で $8.1 \%$ であり, 多くの地区の農業的土地利用率は いずれの年次においても平均を下回っていた.

6）ペンリス市の人口は, 第 1 次世界大戦と第 2 次世界 大戦の時期を除けば年 $6 \%$ の割合で増加しており, そ の割合はオーストラリアにおける都市の平均值の約 2 倍になっている.

7）ペンリス市では工場立地にともなう環境悪化を懸念 して，環境に対する負荷の少ない工場を誘致するよう 努めている，その結果, 電子部品工場や機械組立工場, 食品工場などが立地した。

8）輪換放牧とは，放牧地をいくつかの牧区に区分し， 家畜を 1 つの牧区で 10 日から 20 日間放牧した後, 家 畜を次の牧区に移動させて放牧する方法である。

9) ペンリス湖計画はシドニーオリンピックのボートと カヌー会場を建設する目的で 1990 年に計画され, 1995 年に完成した。

10）市乳の生産割当制度は市乳を計画的に生産するため, ミルクボードが生産量をあらかじめ割当量として決め ている、ペンリス市キャスルレイ地区の 1 農場当たり の割当量は 1 日約 $650 \mathrm{~kg}$ であり, シドニー都市圈の それ $(630 \mathrm{~kg})$ よりもやや多い.

11）シドニー都市圈の近郊や周辺農村では土地価格の上 昇により，農場が団地としてそのままの規模で販売さ れることは少ない. 実際には，1つの農場はいくつか に分割して販売されており，そのことが土地の細分化 (land subdivision) として社会的問題にもなっている.

12） 1 つの土地区画の面積は農場の経営タイプによって 異なる. 1984 年のペンリス市キャスルレイ地区におい て，1つの土地区画の平均面積は酪農場と牧羊農場で 約 80 ha であり, 軽種馬飼養農場と園芸農場でそれぞ れ約 60 ha と約 25 ha であった.

\section{文献}

Best, R.H. (1981): Land use and living space. Methuen, London, 197p.

Blair, A.M. (1980): Urban influences on farming in Essex. Geoforum, 11, 371-384.

Bowler, I.R. (1984): Agricultural geography. Prog. in Hum.Geogr., 8, 256-262.

Bryant, C.R. (1973): The anticipation of urban 
expansion. Geogr. Pol., 28, 93-115.

Bryant, C.R. (1981): Agriculture in an urbanising environment, a case study from the Paris region, 1968 to 75. Can. Geogr., 25, 27-45.

Bryant, C.R. (1984): The recent evolution of farming landscapes in urban-centred regions. Landscape Planning, 11, 307-326.

Bryant, C.R. and Coppack, P.M. (1991): The city's countryside. Bunting, T. and Filion, P. eds.: Canadian cities in transition. Oxford University Press, Toronto, 209-238.

Bryant, C.R. and Johnston, R.R. (1992): Agriculture in the city's countryside. Belhaven Press, London, 233p.

Bryant, C.R., Russwurm, L.H. and McLellan, A.G. (1982): The city's countryside, land and its management in the rural-urban fringe. Longmans, London, 272p.

Burnley, I.H. (1982): Population, society and environment in Australia. Shilling House, Melbourne, $150 \mathrm{p}$.

Department of Planning (1991): Urban bushland, management guidelines. The New South Wales Government, Chatswood, 20p.

Department of Planning (1995): Cities for the 21st century. The New South Wales Government, Chatswood, 136p.

Environment Protection Authority (1995): New South Wales state of the environment 1995. The New South Wales Government, Chatswood, 384p.

Griffin, E. (1973): Testing von Thünen's theory in Uruguay. Geogr. Rev., 54, 564-571.

Heathcote, R.L. (1994): Australia. second edition. Lomgman Scientific and Technical, Essex, 298p.

Ilbery, B.W. (1985): Agricultural geography. Oxford University Press, Oxford, 229p.

菊地俊夫 (1994): ニュージーランドのオークランド都市 周辺農村における農業的土地利用の变化とその地域的 性格, マヌカウ市クレヴドン地区の場合. 地学雑誌, 103, 377-397.

菊地俊夫・モラン ワレン $(1990)$ : ニュージーランドの オークランド都市圈における農業的土地利用の変化と その地域的性格, マヌカウ市イースト・タマキ地区の 事例. 地理学評論, 63A, 741-765.

菊地俊夫・鷹取泰子 (1999): 東京大都市圈の都市周縁部 に打ける農業的土地利用の変化と持続性, 東京都調布 市下布田地区の事例. 地域研究, 40, 1-16.
菊地俊夫·堤 純 (1998): 都市近郊農村に打ける農業的 土地利用の持続性と変移性一前橋市近郊の養䖯農村元 総社地区の事例一. 季刊地理学, 50, 1-16.

Mather, A.S. (1986): Land use. Longman, New York, $286 \mathrm{p}$.

Moran, W. (1978): Land value, distance and productivity on the Auckland urban periphery. N.Z. Geogr., 34, 85-96.

Moran, W.(1979): Spatial patterns of agriculture on the urban periphery, the Auckland case. Tijdschr. Econ. en Soc. Geogr., 70, 164-176.

Moran, W. (1980): Mechanisms of land use allocation on the urban periphery, an Auckland case. Anderson, A.G. ed.: The land our future. Longman Paul and N.Z. Geogr. Soc., Auckland, 223-238.

Munton, P.J.C. (1974): Farming on the urban fringe. Johnson, J.H. ed.: Suburban growth, geographical processes at the edge of the western city. John Wiley and Sons, London, 201-223.

Newton, P.W. and Bell, M. (1996): Population shift, mobility and change in Australia. Australian Government Publishing Service, Canberra, 443p.

Pacione, M. ed. (1986): Progress in agricultural geography. Croom Helm, London, 267p.

Pryor, R.J. (1968): Defining the rural-urban fringe. Social Forces, 47, 202-215.

Rhind, D. and Hudson, R. (1980): Land use Methuen, London, 272p.

Russwurm, L.H. (1980): Land in the urban fringe, conflicts in their policy implication. University of Waterloo, Department of Geography, Publication Series, 15, 453-505.

Sinclair, R. (1967): Von Thünen and urban sprawl. Ann. Assoc. Amer. Geogr., 57, 72-88.

State Planning Authority of New South Wales (1973): The new cities of Campbelltown Camden Appin, structure plan. The State Planning Authoruty of New South Wales, Sydney, 143p.

田林 明・菊地俊夫 (2000): 持続的農村システムの地域 的条件. 農林統計協会, 513p.

Young, A. (2000): Environmental change in Australia since 1788. Oxford University Press, South Melbourne, 243p.

(2001年 5 月 9 日受付， 2001 年 10 月 22 日受理) 